\title{
A Prototype of Salt Gradient Solar Pond as Alternative Energy Source for Coastal Communities in Bengkulu
}

\author{
Afdhal Kuniawan Mainil* \\ Mechanical Engineering Department, Engineering Faculty \\ University of Bengkulu, \\ Indonesia
}

*corresponding author: Afdhal Kuniawan Mainil, mainilafdhalk@unib.ac.id

\begin{abstract}
One of the developing technologies of renewable energy is the Salt Gradient Solar Pond (SGSP). SGSP utilize solar energy by storing its thermal energy in a pond of saline solution. Bengkulu Province has a high intensity of sunlight and a long coastline with an abundance of salt water. Therefore, it is a very suitable location for further development of SGSP technology. The design of SGSP prototype had been carried out by using a $1 \mathrm{~m}^{3}$ cylinder as the saline solution pond. The density and temperature of the solution were measured at 11 points from the bottom to the top of the cylinder. The results show that the keeper of the pond, the more density of the solution, in which the highest solution density was at the bottom of the pond, i.e., $1.206 \mathrm{gr} / \mathrm{cm}^{3}$. The average temperature of the solution was 44.2 ${ }^{\circ} \mathrm{C}$. The maximum temperature, which was $48.7^{\circ} \mathrm{C}$, was observed around the storage zone, about $0.3 \mathrm{~m}$ from the pond's bottom. The results of the measurements of salinity gradient and temperatures show that this prototype of SGSP is appropriate to be used for storing heat around the storage zone.
\end{abstract}

Keywords- Salt Gradient Solar Pond (SGSP), Bengkulu coastline, density, temperature, renewable energy.

\section{INTRODUCTION}

The subtitle should be labeled as 1.0, 2.0, etc. Nowadays, the energy crisis in the world is very worrying because it is closely linked to the survival of human life in the future. Koyama [1] reported that The global share of energy source as of 2040 would be led from $29 \%$ oil, $25 \%$ from natural gas, $24 \%$ from coal, $14 \%$ from renewable energies excluding hydropower (solar energy, wind energy, etc. ), 6\% from nuclear, and $2 \%$ from hydropower. It can be predicted with the sophisticated increase in technology, as well as the increase in energy needs. It had been reported that the availability of fossil energy such as crude oil, coal, natural gas was predicted no more than 150 years [2]. On the other hand, global warming becomes another serious problem which needs to be overcome immediately.

One of the energy sources is solar energy. The sun as the center of the solar system has a magnitude of radiation about $3,85 \times 1023 \mathrm{~kW}$. The atmosphere absorbs most of the solar radiation moreover at least earth receives the heat about 990
$\mathrm{W} / \mathrm{m}^{2}$ in coastline [3]. Alternative energy sources developed is salt gradient solar pond (SGSP) technology [4]. It is a salt solution pond functioned to collect solar radiation and to save the energy for a certain time. Heat energy can be used for various purposes including heater, dryers, distillation, and particularly as a source of power [5-9].

Bengkulu province is a region that has long coastline which reaches $525 \mathrm{~km}$. Therefore, Bengkulu has a large potential to develop salt gradient solar pond technology. At least there are two primary assets supporting the application of salt gradient solar pond in the coastline of Bengkulu. Firstly, Bengkulu has tropical climates which have an abundance of sunlight intensity. Secondly, Bengkulu has a long coastal region which leads to the availability of plenty of raw salt materials. Consequently, salt gradient solar pond technology is one of the simplest technologies in the design and low in cost, which can directly transform solar energy into heat energy $[10,11]$.

\section{METHODOLOGY}

The prototype of The prototype of Salt Gradient Solar Pond (SGSP) is shown in Figure 1. Salt Gradient Solar Pond prototype has $1 \mathrm{~m}^{3}$ volume of tank for storing saltwater solution. The tank was coated by thermal insulation made of glass wool and aluminum foil (first and second layer respectively) to minimize heat losses during storage. Furthermore, these coatings were functioned to optimize the absorption of solar radiation. It is also aided by giving a black plastic at the base of the tank.

The tank was equipped with a sampler device for taking the salt solution at several points on saltwater layers. Afterward, the taken samples were employed to measure the density. The Measurement of temperature used $\mathrm{K}$ type thermocouples. Thermocouples were temperature gauge placed at several test points. The image of SGSP prototype can be seen in Figure 1. 


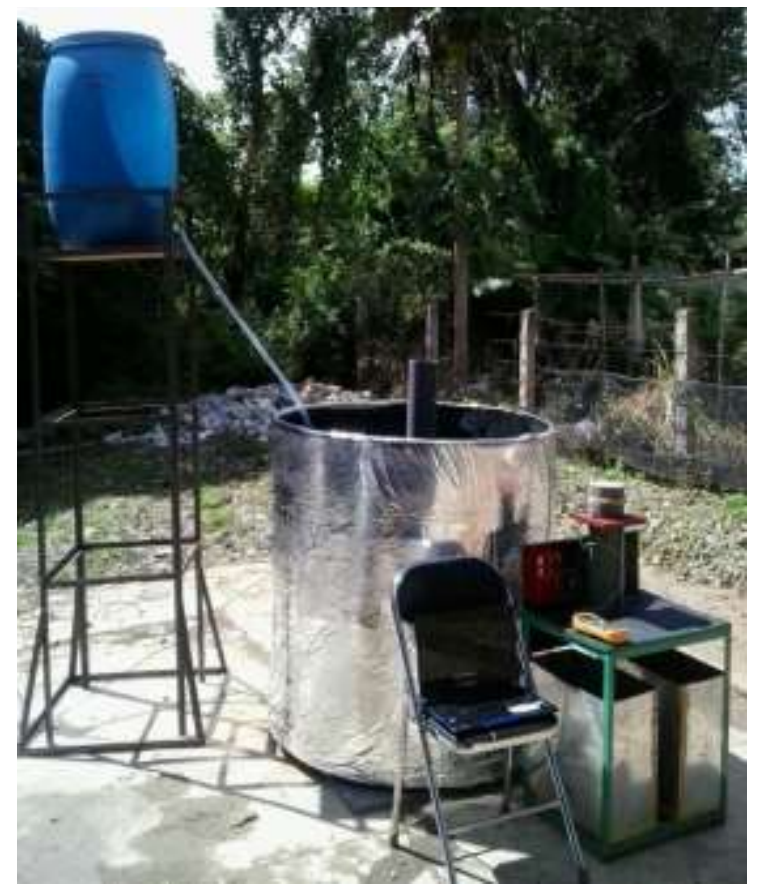

Figure 1: The prototype Salt Gradient Solar Pond (SGSP)

The tank was equipped with tank filler, and the stand put beside it. The filler tank was used to mix water and salt to arrange the salinity level of each layer. Sampler position and $\mathrm{K}$ type thermocouple were positioned from the bottom to the top with 1 meter of height. The distance between each point is $0.1 \mathrm{~m}$ as shown in Figure 2. Thermocouples were connected with data acquisition as the output of temperature readings. Measurements of density were carried out by taking samples as much as $10 \mathrm{ml}$ at 11 test points. Furthermore, the density was measured using a pycnometer.

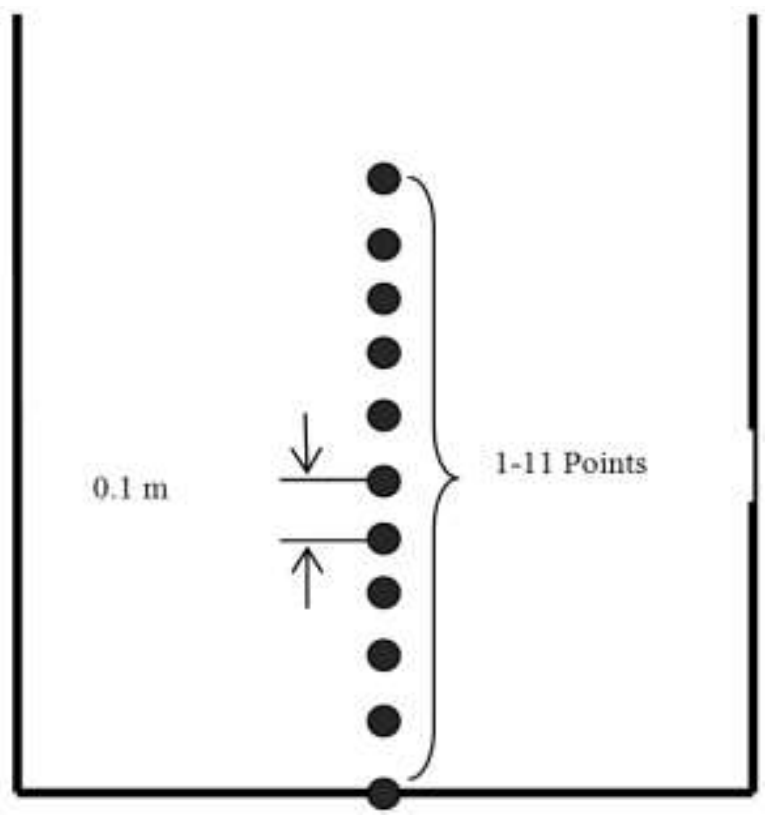

Figure 2. Arrangement of test points

\section{RESULT AND DISCUSSION}

Figure 3 shows the density profile for each test points with a variety of height on the SGSP prototype. Based on the density measurements at each test points, the highest density around $1.2 \mathrm{~g} / \mathrm{cm}^{3}$ was visible at the bottom of the pool, as shown in Figure 3. The layer was used as the heat storage layer or storage zone. It was by the temperature measurements at each point of the tests at several different times.

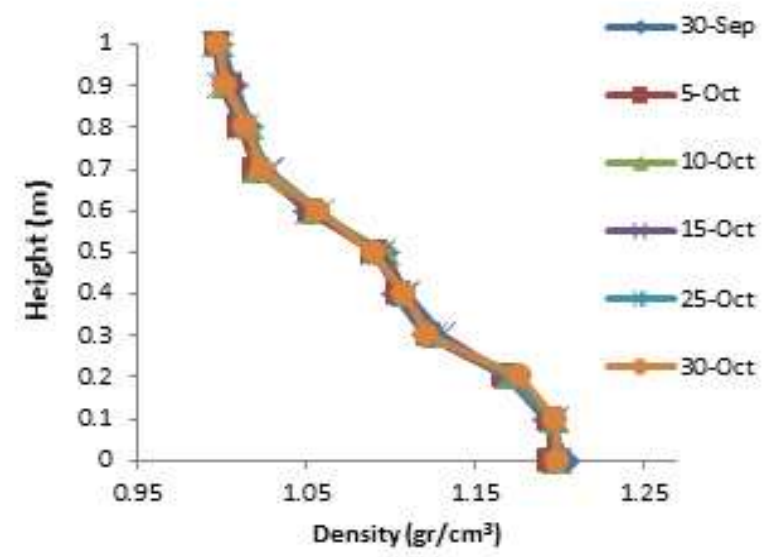

Figure 3. Density Profile of Test Points

The salinity of test points with a different height (meter) in the storage tank with a variation of density $\left(\mathrm{gr} / \mathrm{cm}^{3}\right)$ is shown in Figure 4. It can be seen that the highest density obtained was at the bottom of the pool. Here in, the density value increase with the decreasing of depth or reach the bottom of the pool. The increment of density tends to be linear, along with the depth until it reached the bottom of the pool. Each symbol in Figure 4 expresses the depth to the bottom of the pool.

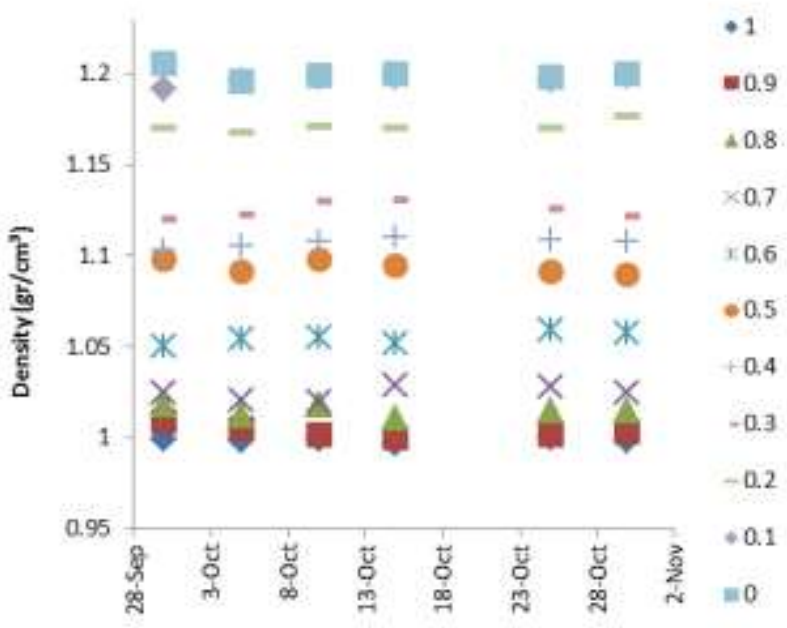

Figure 4. The salinity of Test Points 


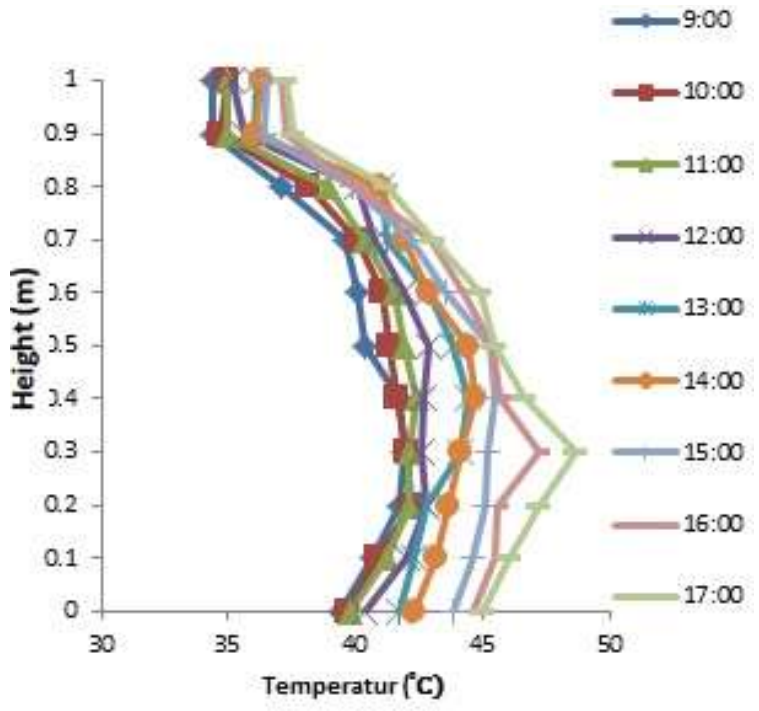

Figure 5. Distribution of temperature in different height

The temperature distribution at different height of the pool in a solar pond is shown in Figure 5. The temperature distribution tends to be like parabolic, where the temperature increased with the increasing of heating time from 9:00 AM until 5:00 PM. The temperature reached a peak around 3:00 PM at $0.3 \mathrm{~m}$-height in each hour data captured. The highest temperature achieved was $48.7^{\circ} \mathrm{C}$ in the storage area of the zone at a height of $0.3 \mathrm{~m}$ from the bottom of the pond at around 3:00 PM.

Figure 6 shows the average temperature distribution on the height (m) of the Salt Gradient Solar Pond (SGSP) prototype for six days of data captured. Similarly, the temperature distribution tends to be like parabolic compared to Figure 5, where temperature increases with the decreasing of the height of pool depth. The temperature of liquid reached a peak around $0.3 \mathrm{~m}$ height in each day of data captured. The highest average temperature for whole experiments was $44.2^{\circ} \mathrm{C}$ at 5 October data obtained.

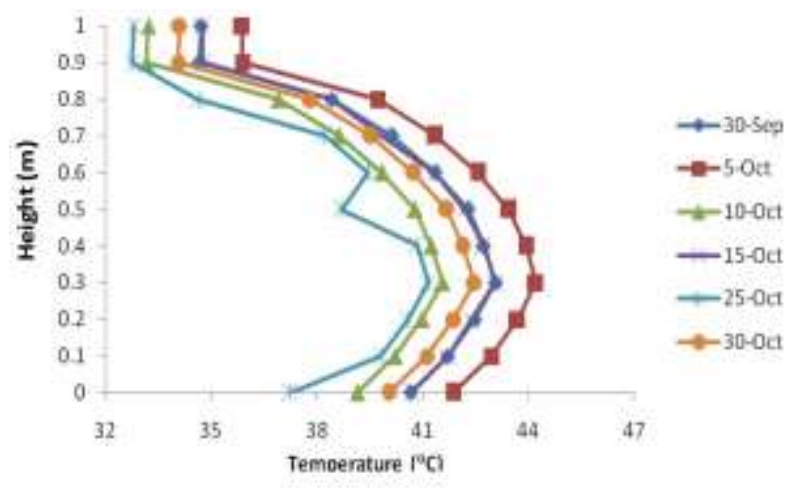

Figure 6. The average temperature on the height of the entire testing time

\section{CONCLUSION}

Overall, there was a gradual increase in the density of SGSP from top to bottom. It was indicated that the layer formation SGSP going well, and the largest density at the bottom of the pool was $1.2 \mathrm{~g} / \mathrm{cm}^{3}$. Therefore, it can be concluded that the zone of storage prototype was located in these particular areas, which have a higher density than others. While the highest average temperature in the whole experiments was $44.2^{\circ} \mathrm{C}$ and the highest temperature that could be achieved was $48.7^{\circ} \mathrm{C}$ in the storage area of the zone at the height of $0.3 \mathrm{~m}$ from the bottom of the pond. It reveals that the salinity and temperature gradient of SGSP prototype has been already well and can be used to store the heat in the storage area of the zone.

\section{ACKNOWLEDGMENT}

Thanks to the Research Institute of the University of Bengkulu on operational assistance grants competition Universities (BOPT), Laboratory of Production Engineering, Mechanical Engineering UNIB and Energy Conversion Laboratory for the assistance during the process of testing and research.

\section{REFERENCES}

[1] Koyama, K, "The Role and Future of Fossil Fuel", IEEJ Energy Journal, Special Issue, pp. 80-83, 2017.

[2] Indartono, Y.S, "Energy dan Perubahan Iklim", Program Studi Teknik Mesin ITB, 2010.

[3] Rashid. F.L, Fayyadh. I. K, and Hashim. A, "Design of Solar Pond for Electricity Production", British Journal of Science Vol. 3 (2), pp. 104$110,2012$.

[4] Akbarzadeh, A., Andrews, J., Golding, P., Solar Ponds., Solar Energy Conversion and Photoenergy Systems, Vol. 1.

[5] Valderrama, C., Gibert, O., Arcal, J., Solano., Akbarzadeh, A., Larrotcha, E., Cortina, J.L, "Solar Energy Storage by Salinity Gradient Solar Pond: Pilot Plant Construction and Gradient Control", Desalination Vol. 279 (1-3), pp. 445-450, 2011.

[6] Srinivasan. J, "Solar Pond Technology", Sadhana. Vol 18. Part 1, pp. 39-55, 1993.

[7] Singh. R., Tundee.S., Akbarzadeh. A, "Electric Power Generation From Solar Pond Using Combined Thermosyphon and Thermoelectric Modules", Solar Energy Vol. 85 (2), pp. 371-378, 2011.

[8] Jaefarzadeh.M.R, "Thermal Behavior of a Small Salinity-Gradient Solar Pond with Wall Shading Effect", Solar Energy, Vol. 77 (3), pp. 281-290, 2004.

[9] Egbe. J.G., Khan.A.H., Wisatesajja. W, "Design of Solar Pond Calculation and Technique in Africa", IOSR Journal of Mechanical and Civil Engineering, Vol. 6 (1), pp. 22-32, 2013.

[10] Sharif, A. O., Al-Husaini- H., Alenezi, I.A, "New Method for Predicting the Performance of Solar Pond in any Sunny Part of the World", World Renewable Energy Congress-Solar Thermal Applications, Sweden, 2011.

[11] Lu, H., Walton, J.C., Swift, A. H. P, "Desalination Coupled with Salinity-Gradient Solar Ponds", Desalination Vol. 136 (1-3), pp. 13-23, 2001. 